\title{
The Effect of Transparency, Competency and Religiosity on Public Officers' Ethical Behaviour
}

\author{
Mazurina Mohd Ali ${ }^{1}$, Nurul Izzah Mohamed Azam ${ }^{1} \&$ Erlane K Ghani ${ }^{1}$ \\ ${ }^{1}$ Faculty of Accountancy, Universiti Teknologi MARA, Puncak Alam, Selangor, Malaysia \\ Correspondence: Erlane K Ghani, Faculty of Accountancy, Universiti Teknologi MARA, 42300 Puncak Alam, \\ Selangor, Malaysia. Tel: 60-3-3258-7327.
}

Received: April 20, 2019

Accepted: May 7, 2019

Online Published: May 19, 2019

doi:10.5430/ijfr.v10n3p181

URL: https://doi.org/10.5430/ijfr.v10n3p181

\begin{abstract}
This study examines the relationship between transparency, competency and religiosity with the ethical behaviour of the public officers in Malaysia. This study utilises the questionnaire survey as the research instrument distributed to the public officers from eleven enforcement agencies in Malaysia. Using multiple regression analysis on 71 respondents, this study shows that both transparency and competency have significant relationship with the ethical behaviour of the public officers in the enforcement agencies, and the relationship is significant. Personal actions and interpersonal relationships, two-way communication, reinforcement, and decision-making are among the factors contributing to the significant relationship. However, religiosity does not have a significant relationship on the public sector officers' ethical behaviour. The findings from this study provide some implications towards the enforcement agencies in improving their ethical behaviour in performing their tasks. This is because transparency and competency play an important role in improving ethical behaviour in the work place.
\end{abstract}

Keywords: transparency, competency, religiosity, ethical behaviour, public officers, Malaysia

\section{Introduction}

Since 1980, the Malaysian government has taken various ongoing efforts to instil positive values and work ethics among their officers. The government has used efforts such as Leadership by Example (1983); Name Tag (1985); Application of Islamic Values (1985); Clean, Efficient and Trust (1989) and Excellent Work Culture (1989). These efforts are among the key initiatives or goals expected by the government to foster positive value, thus supporting the value of transparency and competency among its officers (Ishak, Osman, Ghafarullahhuddin \& Manan. 2016; Lari, NYangweso \& Rono 2017). In addition, the government has also introduced various programs to improve governance quality such as Quality Management, ISO 9000 series, Client Charter and Benchmarking. These programs are expected to have a significant impact on the governance quality.

In 2009, the former Prime Minister of Malaysia, Dato' Sri Mohd Najib Abdul Razak introduced the concept of 'Work Culture, Performance Now' which is part of the Gagasan 1Malaysia Project. This concept is an improvement to the second pillar in the Ninth Malaysia Plan (RMK-9) which aims to enhance knowledge and innovation in order to develop a world class mind among the public officers. From these programs, the government has taken drastic actions to improve the quality of public services. However, Abdullah, Chiet, Anuar and Shen, (2004) stated that the government has received many complaints regarding its officers' unethical behaviour and corruption practices. The Malaysian Anti-Corruption Commission (MACC) Malaysia reported that the number of integrity cases involving the public officers in Malaysia involving ordinary management/subordinate managers have large collusions of integrity with 248 cases in 2014; 229 cases in 2015 and 178 cases in 2016. The professional management occupied the second half of 2014 with 37 cases; 91 cases in 2015 and 66 cases in 2016. On the other hand, the upper category has a slightly lower integrity status in 2014 with 8 cases; 3 cases in 2015 and no case in 2016 . Thus, this raises a concern on the factors influencing the public officers' ethical behaviour.

This study aims to examine the influence of task transparency, task and decision competency and religiosity of the public officers on their ethical behaviour. The remainder of this paper is structured as follows. The next section, Section 2 provides the literature review. Section 3 provides the research framework and hypotheses of this study. This is followed by Section 4 that outlines the research design. The results of the data analyses are shown in Section 5. The last section concludes this study. 


\section{Literature Review}

\subsection{Ethical Behaviour}

Ethical behaviour is a process of reflection and community exercise that concerns with individuals' moral ethical behaviour often based on the individuals' value standards (Bishop, 2013; Hassan, Wright \& Yukl, 2014; Lupu, 2017). Ethical behaviour enables individuals to balance and make the right decisions in their workplace (Suhonen, Stolt, Virtanen \& Leino-Kilpi, 2011). Application of good ethics in the work place is important to ensure that all employees would work ethically in safeguarding their organisation's resources. There are several methods in implementing ethical behaviour in an organisation which are categorised into formal method and informal method. The organisation can use a formal method such as formal guidelines that specify the ethical code of conduct in the organisation. An organisation can also use informal method such as the supervisors presenting good examples of ethical behaviour to their subordinates. Good norms and culture that are implemented in an organisation may also lead to the good ethical behaviour of its employees (Adam \& Rachman-Moore, 2004). Arguably, the public sector can be seen as an individual that is constantly changing through socio-political development, environmental influence and new leadership (Lynch, 1999).

All government agencies need to be effective and efficient in managing their public funds to ensure that the public funds are effectively and efficiently managed. Effective and efficiency public fund management encompass the qualitative and value-laden expectation of the public (Kishore \& Derek, 2005; Lee,Ismail \& Sanusi 2018). Hence, good ethical behaviour is important in the public sector as its main mission is to ensure that the public interest is safeguarded. This can be done through effective governance system that can protect the rights of the public and demonstrates accountability and ethical behaviour from the public officers in their daily tasks (Mutula, 2009). However, studies have also suggested that employees' ethical behaviour can be influenced by various factors such as transparency, competency and religiosity.

\subsection{Transparency and Ethical Behaviour}

Transparency is the magic word in preventing corruption and unethical behaviour among employees. Employees that are lacking in morality can be prevented because they know that they are being monitored and therefore, would not let their personal interests prevail over the interest of their stakeholders (Wan Mohd Fathi, Ghani, Said \& Puspitasari, 2017). Transparency is not just about the existence of a freedom of information act, but also about the intensity with the preference of the media that the public use to convey their rights and acts through information requests and litigations that induce transparency. The media must not be bias towards the public so that the transparency and the reliability of the media and government can be upheld. This is because the government often control and treat the media as its alliance partners (Marquette, 2015; Madhusudhanan, 2018).

In most countries, the government requires transparency and fairness to combat unethical behaviour among the officers (Cunningham \& Darling, 2016). The implementation of transparency will reduce corruption and unethical behaviour among the public officers as they need to report all their activities to the public (De Vries \& Sobis, 2016). Furthermore, the effectiveness of transparency is further enhanced by administrative simplicity, the high standards of auditing and accounting in the private sector as well as in the public sector, and the presence of a critical and engaged of civil society, an independent judiciary and independent, critical and investigative media (De Vries \& Sobis, 2016). It shows that the government has nothing to hide on the way they manage and maintain public sources and the safety of the public. Other studies have argued that in order to reduce the discretion of public sector officers, there is a need to improve transparency, accountability and monitoring, and increase sanctions on those calculations of the agent that result in malfeasance (Marquette, 2015).

\subsection{Competency and Ethical Behaviour}

Competency is defined as an individual's underlying characteristic that is related to superior task performance that might take the form of a motive, skill, body of knowledge or some other aspect of one's self-image or social role. In all departments or organisations, the leaders are the individuals that play an important contribution toward organisational successful. This is because good leaders would be able to lead their subordinates to achieve organisational targets. Leaders in the public sector play a key role in improving performance and their competency would be important to achieve success. The competency approach is an approach used to improve performance is the centred-on inputs such as the knowledge, skills, and the abilities for success that the leaders bring to the organisation as well as other personal qualities needed to become successful (James, 2016; Manesh, Singh \& Hussain 2018).

There are negative and positive in the public officers' competency in managing public interest. The positive perspective of competency is the ability to manage public interest. In addition, it also includes the ability to assess 
the impact of the decisions to the public and ensuring that the decisions are illustrated fairness and equity values, and being rational and systematic (Kelman, 2007). The terminal values also include serving the public good and working with personal integrity might shape the competency relating to communicating in a political environment, managing the political environment and interpersonal motivational skills of the officers in the public sector that lead to ethical behaviour (Cunningham \& Darling, 2016). On the other hand, the negative perspective of competency in the public sector is the competency to make decisions that are used in the private sector may not work well in government since in the government, decision-making is often slow and takes into account a broader consideration of issues (Cunningham \& Darling, 2016).

\subsection{Religiosity and Ethical Behaviour}

Religion includes in particular the belief in inspirational reality or spiritual, spiritual beings marked by the beliefs that are held and the practice in which the believer engages, and the relationship with religious organisations (Marquette, 2015). Gert (2011) defined morality as either: (1) descriptively, referring to the ethical code posed by society or other groups, such as religion, or accepted by an individual for his own conduct; or (2) normatively, referring to the code of conduct that, given the stated conditions, will be submitted by all rational persons. In this sense, religion can certainly, and most often is, morally concerned, but morals do not have to worry about religion.

Religiosity refers to a person's tendency to identify with divine truth, miracles, prayers and individuals as spiritual people. Difficulties with religious study arise from religious transformation from public jurisprudence to private, putting it beyond rational dialogue (Neusner, 1988). However, spirituality can be connected to the ability to establish a meaningful relationship between the inner self, the other person and God (God) through faith, hope and affection. The connection between integrity and spirituality was established by Driscoll and McKee (2007) concluded that spirituality involved the understanding of the source of personal values, and how it relates to ethics at work. In a Malaysian context, religiosity in integrity studies is defined as pure values in, interpersonal-interactive worship, and religious ritual or formal religious self-reliance (Ezhar, Rahim, Zainal Abidin, Rezal \& Zamre, 2007).

\section{Research Framework and Hypotheses}

Figure 1 depicts the research framework of this study. The framework shows that there are three independent variables namely; transparency; competency and religiosity. On the other hand, ethical behaviour among the public officers in task performance is the dependent variable.

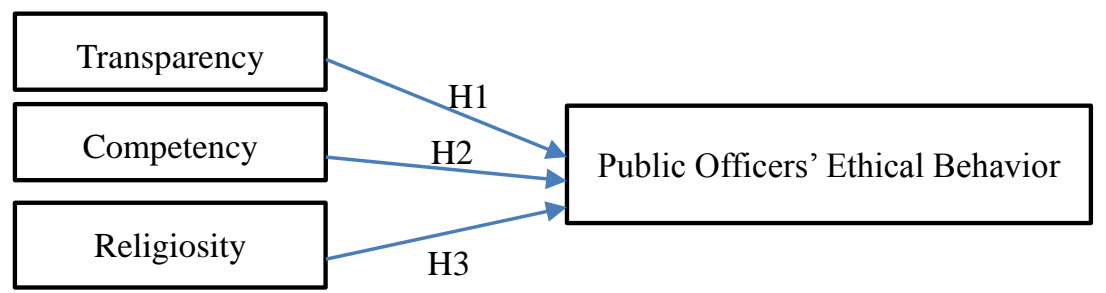

Figure 1. Research framework of this study

Studies have shown that task transparency prevents corruption and unethical behaviour among the officers in the public sector. In most countries, the government requires transparency and fairness to combat unethical behaviour among the officers (Cunningham \& Darling, 2016; Kubat \& Dedebali 2018). The implementation of transparency will reduce corruption and unethical behaviour among the public officers as they need to report all their activities to the public (De Vries \& Sobis, 2016). Therefore, this study develops the first research hypothesis:

H1: Task transparency significantly influences the ethical behaviour of the public officers in managing public funds and other activities in the country.

The public sector competency is unique and reflects to the distinctive features of the public sector environment. It is described as exhibiting and more complex and irresolvable problems. The goals of the government are generally more defined because politicians and managers would try to respond to balance their action or decision between the politicians that have the power with the public that have given their entrustment to them. They are also likely to be closely connected to the unique values found in the public sector. The terminal values of serving the public good and working with personal integrity would shape the competency relating to communicating in a political environment, managing the political environment, interpersonal motivational skills, adding value to clients (Cunningham \& Darling, 2016). Thus, this study develops the second research hypothesis: 
$\mathrm{H} 2$ : Task and decision competency significantly influence the ethical behaviour of the public officers in managing public funds and other activities in the country.

Religiosity provides many researchers with ethical language and is often described as the true 'list' of rules for living with, some that can be interpreted as most important in combating dishonesty. The basis for increasing attention given to religion - the fraudulent relationship generally stems from the argument that equality and honesty are the basis of many religions (Luxmoore, 1999). According to Marquette (2015), there are two clear assumptions underlying the call of religious leaders and groups in the fight against dishonesty. The first assumption is that faithful devotees to religion will abstain from corruption because of the existence of theft, cheating, illegal, and other bad service of others. The second assumption is that non-religious believers are more likely to engage in corruption because of lack of religious guidance. However, contrary to these assumptions, many of the world's most corrupt nations based on the Transparency International's Corruption Perception Index (TI-CPI) are at a higher level of religious affiliation. However, there is a limited study that examines the possible relationship between religiosity and integrity. Therefore, the third research hypothesis is developed in this study:

H3: Strong religiosity significantly influences the ethical behaviour of the public officers in managing public funds and other activities in the country.

\section{Research Design}

\subsection{Sample Selection}

This study selects officers that are attached to eleven enforcement agencies. The officers are selected based on purposive sampling (Palys, 2008). Purposive sampling is suitable in this study because the officers in the enforcement agencies are the ones that need to perform ethically and their role includes encouraging other agencies to perform ethically or to combat other agencies' unethical behaviour. The list of enforcement agencies in Malaysia are Royal Malaysia Army, Royal Malaysia Navy, Royal Malaysia Air Force, Royal Malaysia Police, Prison Department of Malaysia, Malaysia Anti-Corruption Commission, Immigration Department of Malaysia, Malaysian Anti-Drug agencies, National Registration Department of Malaysia, Department of Registration Association Malaysia, and RELA Malaysia. The list of enforcement agencies has been provided by the official Portal of Ministry of Home Affairs and Ministry of Defence Malaysia. The exact of total number of enforcement agencies members is confidential. Thus, in determining the sample size of this study, the approach by Tabahnick and Fidell (2013) is adopted. According to them, the calculation of the approach is as follows:

$\mathrm{N}>50+8 \mathrm{k}$

*where $\mathrm{k}=$ all the predictors.

By using this approach, the minimum sample size that need to be collected is $\mathrm{N}>50+8(2 \mathrm{IV})$ equal to 66 respondents.

\subsection{Research Instrument}

This study utilises the questionnaire survey as the research instrument. This study adapts the research instrument from Winkler (2002) for the elements of transparency, Cooper (2000) for the element of competency, Rakodi (2007) for the element of religiosity and ethical behaviour of public officers with some modifications to suit the local context. The questionnaire consists of four sections, namely, sections A, B, C and D. Section A requests the respondents to complete their demographic profile. The respondents are requested to provide their age, gender, level of education and number of services in the organisation. Section B contains of seven questions in measuring transparency such as how the openness of the government data can be accessed by the public, the disclosure of the information regarding the spending data, the procurement data, the collection transparency of the data and the rule that allowing the public to speak directly to the top level of the enforcement agencies. The respondents are requested to complete this section based on 5 point scale ranging from ' 1 ' as strongly agree to ' 5 ' as strongly disagree.

Section $\mathrm{C}$ contains of twelve questions relate to competency. The questions on competency include capability in making decision for the public, the capability in handling the situation and the capability in practicing rule and regulation. The last section, Section D also comprises of twelve questions that relates to the dependent variable of this study. The questions in this section include the measurement of ethical behaviour such as ethical policies and ethical attitude applied in the organisation. For section C and D, the respondents are also requested to complete this section based on 5 point scale ranging from ' 1 ' as strongly agree to ' 5 ' as strongly disagree.

\subsection{Data Collection}

The data were collected from the top level, middle level and equivalent at eleven enforcement agencies. The questionnaires were distributed to the respondents through Google form. The link to the Google form was shared to 
the targeted respondents through social media such as Whatsup, Facebook, email and tweeter over a period of one month from 01 October 2017 until 29 October 2017. The Google form was distributed and shared 200 times in order to get the minimum respondents. After each submission of Google form, follow-ups were conducted after one week of sharing. The data collected was automatically keyed-in in the Microsoft Excel. In total, 71 respondents completed the questionnaire survey.

\section{Results and Discussion}

\subsection{Demographic Profile}

Table 1 presents the descriptive statistics of the respondents' demographic profile. Based on Table 1, the results show that the respondents with the age under 25 years old represent the largest population in this study totalling 37. Twenty five respondents are between 25 to 35 years old whilst 5 respondents are between 45 to 55 years old. The results also show that 3 respondents are between 36 to 45 years old and only 1 respondent is above 55 years old. Most of the respondents that have participated in the questionnaire survey are female. The results show 50 female respondents participated in this study whereas there are only 21 male respondents. Most of the total respondents hold bachelor degree representing 53 respondents. Only 6 and 7 respondents hold Diploma and STPM certificate respectively. Five respondents hold Master holders.

Table 1 also shows the descriptive statistics of the respondents' working experience. The table shows that 36 respondents have less than 1 year working experience. This is followed by 19 respondents that have more than 5 years working experience. Those respondents that have between 2 to 3 years working experience represent the third highest for this study totalling 15 respondents. Only 1 respondent has working experience of between 4 to 5 years.

Table 1. Demographic profile

\begin{tabular}{|c|c|c|c|}
\hline & & Frequency & Percent \\
\hline \multirow[t]{6}{*}{$\overline{\text { Age }}$} & Under 25 years & 37 & $52.1 \%$ \\
\hline & $25-35$ years & 25 & $35.2 \%$ \\
\hline & $36-45$ years & 3 & $4.2 \%$ \\
\hline & $46-55$ years & 5 & $7.0 \%$ \\
\hline & Above 55 years & 1 & $1.4 \%$ \\
\hline & Male & 21 & $29.6 \%$ \\
\hline \multirow[t]{3}{*}{ Gender } & Female & 50 & $70.4 \%$ \\
\hline & Total & 71 & 100.0 \\
\hline & SPM/STPM & 6 & $8.5 \%$ \\
\hline \multirow[t]{5}{*}{ Qualification } & Diploma & 7 & $9.9 \%$ \\
\hline & Bachelor/Degree & 53 & $74.6 \%$ \\
\hline & Masters & 5 & $7.0 \%$ \\
\hline & Total & 71 & 100.0 \\
\hline & Less than 1 year & 36 & $50.7 \%$ \\
\hline \multirow{3}{*}{$\begin{array}{l}\text { Working } \\
\text { Experience }\end{array}$} & $2-3$ years & 15 & $21.1 \%$ \\
\hline & $4-5$ years & 1 & $1.4 \%$ \\
\hline & More than 5 years & 19 & $26.8 \%$ \\
\hline
\end{tabular}

\subsection{Factor Analysis}

Table 2 panel A shows the results of the factor analysis for ethical behaviour that shows the KMO value of 0.877 . The results show that all 12 loading values are between the loading values of 0.517 to 0.835 as shown in Table 2 panel B. Such values indicate an appropriate value of threshold 0.5 and above as suggested by Hair (2011). 
Table 2. Panel A: Factor analysis for ethical behaviour

\section{KMO and Bartlett's Test}

\begin{tabular}{lll}
\hline Kaiser-Meyer-Olkin Measure of Sampling Adequacy. & 0.877 \\
\hline Bartlett's Test of Sphericity & Approx. Chi-Square & 553.435 \\
\cline { 2 - 3 } & $\mathrm{df}$ & 66 \\
\cline { 2 - 3 } & Sig. & 0.000 \\
\hline
\end{tabular}

Table 2. Panel B: Factor loading values for ethical behaviour

\begin{tabular}{ll}
\hline Question & Extraction \\
\hline D1 Does your organisation have a written ethics policy? & 0.652 \\
\hline D2 Does your company require the employees to sign a code of conduct statement? & 0.548 \\
\hline D3 Are ethical behaviours expected out of your leaders? & 0.555 \\
\hline D4 Are ethical behaviours rewarded? & 0.483 \\
\hline D5 Do the leaders in your organisation act ethically? & 0.799 \\
\hline D6 Are the leaders in your organisation honest? & 0.686 \\
\hline $\begin{array}{l}\text { D7 Is the behaviour of your leaders consistent with the stated ethics and values of the } \\
\text { organisation? }\end{array}$ & 0.725 \\
\hline D8 Do the leaders in your organisation employ favouritism? & 0.835 \\
\hline D9 Does your organisation offer training in business ethics? & 0.646 \\
\hline $\begin{array}{l}\text { D10 Do the leaders in your organisation balance the needs of the work with ethical issues } \\
\text { appropriately? }\end{array}$ & 0.733 \\
\hline D11 Does your organisation balance the short term goals with its long term need for success? & 0.656 \\
\hline D12 Do the higher level in your organisation lead by example? & 0.517 \\
\hline
\end{tabular}

Table 3 Panel A presents the results of the factor analysis for transparency that shows the KMO value of 0.813 . This study shows that all 7 loading values as shown in Table 3 Panel B are larger than 0.5.

Table 3. Panel A: Factor analysis for transparency

\begin{tabular}{lll}
\hline KMO and Bartlett's Test & & \\
\hline Kaiser-Meyer-Olkin Measure of Sampling Adequacy. & 0.813 \\
\hline Bartlett's Test of Sphericity & Approx. Chi-Square & 337.333 \\
\cline { 2 - 3 } & df & 21 \\
\cline { 2 - 3 } & Sig. & 0.000 \\
\hline
\end{tabular}

Table 3. Panel B: Factor loading values for transparency

\begin{tabular}{lc}
\hline Question & Extraction \\
\hline $\begin{array}{l}\text { B1 I can confirm that there is free access by the public to timely information } \\
\text { on decisions and performance in the enforcement agencies. }\end{array}$ & 0.825 \\
\hline $\begin{array}{l}\text { B2 I can confirm that there is free access by the public to reliable information on decisions } \\
\text { and performance in the enforcement agencies. }\end{array}$ & \\
\hline B3 There is effective communication, not simply announcements in enforcement agencies. & 0.710 \\
\hline $\begin{array}{l}\text { B4 In the enforcement agencies there is political transparency as a distinct realm of possible } \\
\text { transparency for the public sector. }\end{array}$ & 0.750 \\
\hline
\end{tabular}


B5 In the enforcement agencies there is economic transparency as a distinct realm of possible transparency for the public sector.

B6 In the enforcement agencies there is procedural transparency as a distinct realm of ${ }_{0.868}$ possible transparency for the public sector.

B7 In the enforcement agencies there is operational transparency as a distinct realm of 0.780 possible transparency for the public sector.

Table 4 panel A presents the factor analysis result for competency that shows the KMO value of 0.861 . This study shows that all 12 loading values as shown in Table 4 panel B are within the range of 0.601 to 0.918 .

Table 4. Panel A: Factor analysis for competency

\section{KMO and Bartlett's Test}

\begin{tabular}{lll}
\hline Kaiser-Meyer-Olkin Measure of Sampling Adequacy. & 0.861 \\
\hline Bartlett's Test of Sphericity & Approx. Chi-Square & 529.211 \\
\cline { 2 - 3 } & Df & 66 \\
\cline { 2 - 3 } Sig. & 0.000 \\
\hline
\end{tabular}

Table 4. Panel B: Factor loading values for competency

\begin{tabular}{ll}
\hline Question & Extraction \\
\hline C1 Do you maintain appropriate confidentiality? & 0.627 \\
\hline C2 Do you say "no" to inappropriate requests? & 0.601 \\
\hline C3 Do you show respect for copyright laws? & 0.677 \\
\hline C4 Are you honest when sharing information with others? & 0.793 \\
\hline C5 Do you balance organisational and personal needs? & 0.729 \\
\hline C6 Are you able to avoid conflicts of interest? & 0.611 \\
\hline C7 Are you able to manage your personal biases? & 0.723 \\
\hline C8 Do you respect the diversity within your organisation? & 0.626 \\
\hline C9 Do you utilise your authority properly? & 0.821 \\
\hline C10 Do you challenge yourself to "do the right thing"? & 0.710 \\
\hline C11 Does favouritism ever enter into your decision making? & 0.918 \\
\hline C12 Do you follow orders regardless if they appear unethical? & 0.833 \\
\hline
\end{tabular}

Table 5 panel A presents the results of the factor analysis result for religiosity that shows the KMO value of 0.572 . The results show that all 8 loading values are within the loading value in range of 0.517 to 0.835 as shown in Table 5 panel B.

Table 5. Panel A: Factor analysis for religiosity

\begin{tabular}{lll}
\hline KMO and Bartlett's Test & & \\
\hline Kaiser-Meyer-Olkin Measure of Sampling Adequacy. & .572 \\
\hline Bartlett's Test of Sphericity & Approx. Chi-Square & 676.567 \\
\cline { 2 - 3 } & df & 28 \\
\cline { 2 - 3 } & Sig. & .000 \\
\hline
\end{tabular}


Panel 5. Panel B: Factor loading values for religiosity

\begin{tabular}{ll}
\hline Question & Extraction \\
\hline E1 Do you attend mosque, every day? & 0.982 \\
\hline E2 Do u pray every day? & 0.888 \\
\hline E3 Dou you believe god will punish on your sin? & 0.977 \\
\hline E4 Would you be interested in being a part of ethical behaviour? & 0.876 \\
\hline E5 What effect do you think that experience visits upon your current belief system? & 0.647 \\
\hline E6 Were you ever part of an organised religion? & 0.687 \\
\hline E7 Are you currently part of an organised religion? & 0.871 \\
\hline $\begin{array}{l}\text { E8 Would you say that your beliefs draw from or originate from a particular religion } \\
\text { amalgamation for positive ethical behaviour? }\end{array}$ & 0.892 \\
\hline
\end{tabular}

\subsection{Reliability Analysis}

Table 6 presents the results of the regression analysis for proposed variables. This study shows that the reliability result is significantly better as the value is above the minimum threshold of 0.5 as suggested by Hair (2011).

Table 6. Summary of reliability analysis

\begin{tabular}{lll}
\hline Code & Variables & Reliability value \\
\hline B & Transparency & 0.897 \\
\hline C & Competency & 0.890 \\
\hline D & Ethical Behaviour & 0.913 \\
\hline E & Region & 0.512 \\
\hline
\end{tabular}

\subsection{Correlation Analysis}

Table 7 presents the results of the correlation analysis. The result shows that there is a correlation between the four independent variables namely, transparency, competency, religiosity and ethical behaviour and thus, indicating no multi-collinearity problem between all variables.

Table 7. Correlation summary

\begin{tabular}{|c|c|c|c|c|c|}
\hline & & BTransparency & CCompetency & DEthicalBehavior & EReligion \\
\hline \multirow[t]{2}{*}{ Transparency } & $\begin{array}{l}\text { Pearson } \\
\text { Correlation }\end{array}$ & 1 & $.624^{* *}$ & $.606^{* *}$ & .146 \\
\hline & Sig. (2-tailed) & & .000 & .000 & .227 \\
\hline \multirow[t]{2}{*}{ Competency } & $\begin{array}{l}\text { Pearson } \\
\text { Correlation }\end{array}$ & $.624^{* *}$ & 1 & $.723^{* *}$ & .036 \\
\hline & Sig. (2-tailed) & .000 & & .000 & .768 \\
\hline \multirow[t]{2}{*}{ EthicalBehaviour } & $\begin{array}{l}\text { Pearson } \\
\text { Correlation }\end{array}$ & $.606^{* *}$ & $.723^{* *}$ & 1 & -.128 \\
\hline & Sig. (2-tailed) & .000 & .000 & & .289 \\
\hline \multirow[t]{2}{*}{ Religiosity } & $\begin{array}{l}\text { Pearson } \\
\text { Correlation }\end{array}$ & .146 & .036 & -.128 & 1 \\
\hline & $\overline{\text { Sig. (2-tailed) }}$ & .227 & .768 & .289 & \\
\hline
\end{tabular}




\subsection{Regression Analysis}

Table 8 presents the results of the regression analysis. Based on Table 8, this study shows the existent of a significant relationship between transparency and ethical behaviour of the public officers. The significant value is $<0.000$, indicating a significant relationship between transparency and ethical behaviour. The results also show that transparency contributes $60 \%$ toward ethical behaviour of the public sector officers in Malaysia.

Table 8 . Regression between transparency and ethical behaviour model summary

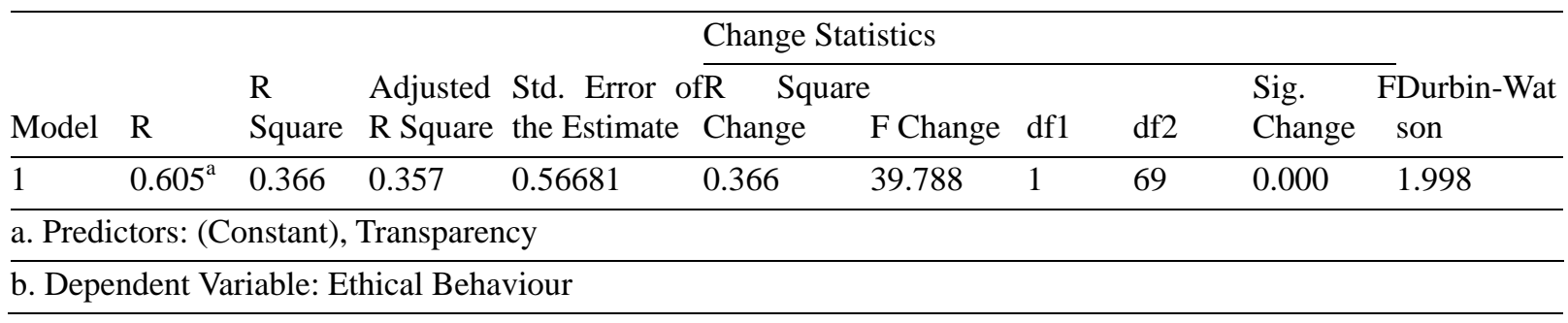

\begin{tabular}{lllllll}
\hline ANOVA $^{\mathrm{a}}$ & \multicolumn{7}{l}{} \\
\hline Model & & Sum of Squares & df & Mean Square & F & Sig. \\
\hline 1 & Regression & 12.783 & 1 & 12.783 & 39.788 & $0.000^{\mathrm{b}}$ \\
\cline { 2 - 7 } & Residual & 22.168 & 69 & 0.321 & & \\
\cline { 2 - 7 } & Total & 34.951 & 70 & & & \\
\end{tabular}

a. Dependent Variable: Ethical Behaviour

b. Predictors: (Constant), Transparency

Coefficients $^{\mathrm{a}}$

\begin{tabular}{|c|c|c|c|c|c|c|}
\hline \multirow{2}{*}{\multicolumn{2}{|c|}{ Model }} & \multicolumn{2}{|c|}{ Unstandardized Coefficients } & \multicolumn{2}{|c|}{$\begin{array}{l}\text { Standardized } \\
\text { Coefficients }\end{array}$} & \multirow[b]{2}{*}{ Sig. } \\
\hline & & $\overline{\mathrm{B}}$ & Std. Error & Beta & $\mathrm{t}$ & \\
\hline \multirow[t]{2}{*}{1} & (Constant) & 1.632 & 0.342 & & 4.774 & 0.000 \\
\hline & Transparency & 0.598 & 0.095 & 0.605 & 6.308 & 0.000 \\
\hline
\end{tabular}

a. Dependent Variable: Ethical Behaviour

Table 9 presents the results of the regression analysis on competency. Based on Table 9, this study shows a significant relationship between competency and ethical behaviour of the public officers. The significant value indicates a significant relationship between transparency and ethical behaviour ( $\mathrm{Sig}<0.050$ ). The results also indicate that competency contributes $72 \%$ toward ethical behaviour of the public officers. The $\mathrm{F}$ value shows competency contributes 75.7 to ethical behaviour of the public officers.

Table 9. Regression between competency and ethical behaviour

\section{Model Summary}

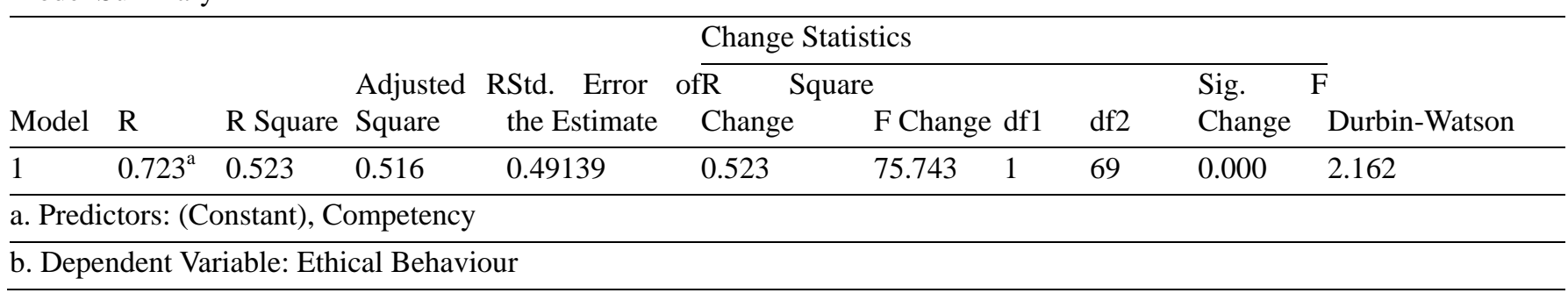




\begin{tabular}{lllllll}
\hline ANOVA $^{\text {a }}$ & \multicolumn{7}{l}{} & & & \\
\hline Model & & Sum of Squares & df & Mean Square & F & Sig. \\
\hline 1 & Regression & 18.289 & 1 & 18.289 & 75.743 & $0.000^{\mathrm{b}}$ \\
\cline { 2 - 7 } & Residual & 16.661 & 69 & .241 & & \\
\cline { 2 - 6 } & Total & 34.951 & 70 & & & \\
\hline a. Dependent Variable: Ethical Behaviour & & & & \\
\hline b. Predictors: (Constant), Competency &
\end{tabular}

\begin{tabular}{|c|c|c|c|c|c|c|}
\hline \multicolumn{7}{|c|}{ Coefficients $^{\mathrm{a}}$} \\
\hline & & Unstan & Coefficients & $\begin{array}{l}\text { Standardized } \\
\text { Coefficients }\end{array}$ & & \\
\hline \multicolumn{2}{|l|}{ Model } & $\overline{\mathrm{B}}$ & Std. Error & Beta & $\mathrm{t}$ & Sig. \\
\hline \multirow[t]{2}{*}{1} & (Constant) & 0.633 & 0.363 & & 1.745 & 0.085 \\
\hline & Competency & 0.802 & 0.092 & 0.723 & 8.703 & 0.000 \\
\hline
\end{tabular}

Table 10 presents the results of the regression analysis for religiosity and ethical behaviour. The results show no relationship between religiosity and ethical behaviour since the value is above 0.05 which shows the value of 0.289 . The ethical behavioural value is 0.000 .

Table 10. Regression between religiosity and ethical behaviour

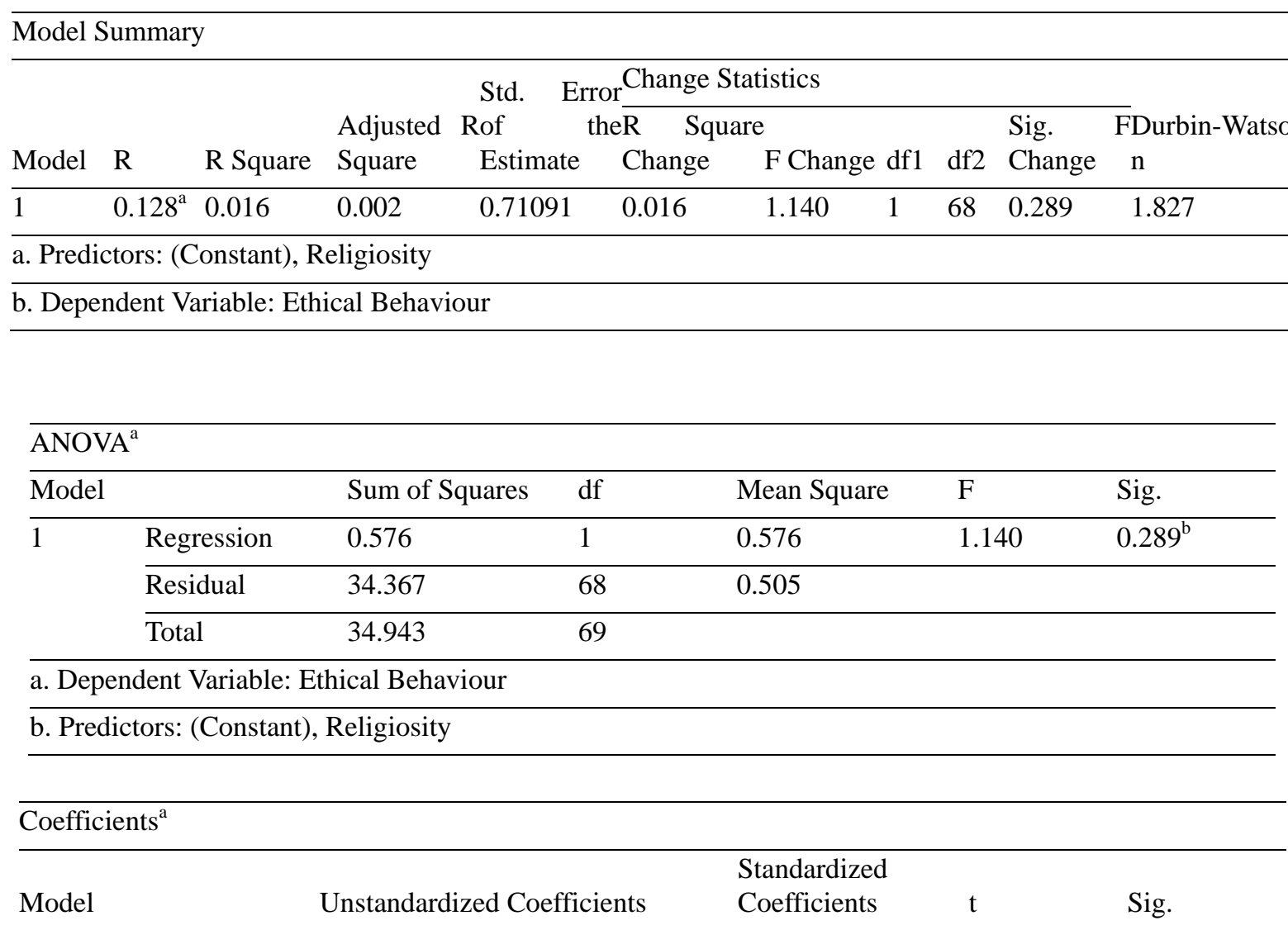




\begin{tabular}{lllllll}
\hline \multicolumn{2}{l}{} & B & Std. Error & Beta & & \\
\hline 1 & (Constant) & 4.786 & 0.978 & & 4.892 & 0.000 \\
\cline { 2 - 7 } & Religiosity & -.278 & 0.260 & -0.128 & -1.068 & 0.289 \\
\hline
\end{tabular}

a. Dependent Variable: Ethical Behaviour

\section{Conclusion}

This study highlights the ethical behaviour of the public officers in this study. The findings in this study indicate that transparency and competency significantly influence the public officers' ethical behaviour. This is done through personal actions and interpersonal relationships, and the promotion of such conduct through two ${ }^{-}$way communication, reinforcement, and decision-making. Researchers have sought to further specify the concept by identifying its key components based on the mode of promoting conduct, notably, being a moral person exemplified by a transparency trait, behaviours, and how he or she makes decision and a being moral manager (Treviño, Brown \& Hartman, 2003). For Hassan et al. (2014), ethical behaviour is made up of being an ethical role model, treating people fairly, and actively managing ethics in the organisation. Overall, although grouped in different ways, the existing literature sorted the effects and actions of the public sector officers in relation to ethics into those emanating from the nature and behaviour of the leader as a person, encouraging emulation, and those arising from the systems and practices that they set up to regulate conduct on their behalf.

Although studies on ethical leadership have grown rapidly, analysis in this field faces a number of concerns. The first of these concerns whether ethical behaviour among public officers is conceptually distinct from other factors such as transparency and competency. The latter entails providing individualised consideration, intellectual stimulation, inspirational motivation, and idealised influence (Bass, 1990). Thus, public officers are in a position to set an example and influence the behaviour of people around them as individuals often learnt by observing and emulating attractive and credible models. The ethical behaviour of leaders also forms a key component of other leadership theories, including authentic leadership, spiritual leadership, and servant leadership (Yukl. 2013). This leads to the second issue on the criticism that ethical behaviour among the public officers remains vague due to lack of focus on the influencing factors.

There are few limitations of this study. The first limitation is that this study only focuses on three factors namely, transparency, competency and religiosity. There are other factors that could affect the ethical behaviour of the public sector, specifically enforcement agencies. The second limitation is that there is no moderating factor on the influence of transparency and competency on the ethical behaviour of the public officers. The moderating factor could help more in supporting the influence of transparency, competency and religiosity on the public officers' ethical behaviour.

The findings from this study could have some implications towards the enforcement agencies in improving their ethical behaviour in performing their tasks. This is because transparency and competency play an important role in improving ethical behaviour in the work place. This study also discovers that lack of transparency can lead to the increasing of the corruption and unethical behaviour among the public officers. In order to ensure public sector perform ethically, the public as a whole need to know the transaction and distribution of the public fund in avoiding the unethical behaviour such as corruption and bribery. This study is significant because it can assist the public officers to identify the factors that can influence their ethical behaviour in the workplace.

\section{Acknowledgements}

We would like to express our gratitude to the Institute of Quality and Knowledge Advancement and the Institute of Research Management and Innovation, Universiti Teknologi MARA for their support in funding this project

\section{References}

Abdullah, F., Chiet, C. V., Anuar, K. \& Shen, T. T. (2004). An overview on the growth and development of the Malaysian construction industry. Workshop on Construction Contract Management. Universiti Teknologi Malaysia.

Adam, M. A., \& Rachman-Moore, Dalia. (2004). The methods used to implement an ethical code of conduct and employee attitudes. Journal of Business Ethics, 54, 225-244. https://doi.org/10.1007/s10551-004-1774-4

Bass, B. M. (1990). From transactional to transformational leadership: Learning to share the vision. Organizational Dynamics, 18(4), 19-31. https://doi.org/10.1016/0090-2616(90)90061-S 
Bishop, W. H. (2013). The role of ethics in 21st century organisations. Journal of Business Ethics, 118(3), 635-637. https://doi.org/10.1007/s10551-013-1618-1

Bock, G. W., Zmud, R. W., Kim, Y. G., \& Lee, J. N. (2005). Behavioral intention formation in knowledge sharing: Examining the roles of extrinsic motivators, social-psychological forces, and organizational climate. MIS Quarterly, 29(1), 87-111. https://doi.org/10.2307/25148669

Cooper, K. C. (2000). Effective Competency Modeling and Reporting. New York: Amacom.

Cunningham, J. B., \& Darling, S. D. (2016). Underlying values and competencies of public and private sector managers. Asian Education and Development Studies. Asian Education and Development Studies, 5(4), 371-387. https://doi.org/10.1108/AEDS-09-2015-0050

De Vries, M., \& Sobis, I. (2016). Increasing transparency is not always the panacea: An overview of alternative paths to curb corruption in the public sector. International Journal of Public Sector Management, 29(3), 255-270. https://doi.org/10.1108/IJPSM-11-2015-0197

Ezhar, T., Rahim, M. S., Zainal Abidin, M., Mohamed Rezal, H., \& Zamre, Y. (2007). Micro Agro-based Entrepreneurs' Readiness in Facing Agriculture Challenges. IPSAS Monograph Series Bil. 1/2007, p. 7, University Putra Malaysia Publisher, Serdang, Malaysia.

Gert, B. (2011). The definition of morality. In E. N. Zalta (Ed.), Stanford Encyclopedia of Philosophy. Stanford, CA: Stanford University.

Hassan, S, Wright, B. E., \& Yukl, G. (2014). Does ethical leadership matter in government? Effects on organizational commitment, absenteeism, and willingness to report ethical problems. Public Administration Review, 74, 333-43. https://doi.org/10.1111/puar.12216

Ishak, A. H., Osman, M. R., Ghafarullahhuddin, D., \& Manan, S. K. (2016). Toward Implementing Islamic Values in Governmental Reforms: A Malaysian Experience Contemporary Issues and Development in the Global Halal Industry. Springer. https://doi.org/10.1007/978-981-10-1452-9_3

James, B. C. (2016). Strategic Human Resource Management in the Public Arena: A Managerial Perspective. London: Palgrave - MacMillan.

Kelman, S. (2007). Public administration and organisational studies. The Academy of Management Annals, 1 , 225-267. https://doi.org/10.1080/078559810

Kishore, R., \& Derek, T. (2005). Impact of accountability and ethics on public service delivery: A South African Perspective, Summer. Nelson Mandela Metropolitan University, Porth Elizabeth, South Africa.

Kubat, U., \& Dedebali, N. C. (2018). Opinions of Science Teachers for Classroom Management. Journal of Education and e-Learning Research, 5(2), 110-117. https://doi.org/10.20448/journal.509.2018.52.110.117

Lari, L. R. A., NYangweso, P. M., \& Rono, L. J. (2017). Determinants of Technical Inefficiency of Saccos in Kenya: A Net Operating Cash Flows Output Slack Analysis. Asian Journal of Economics and Empirical Research, 4(2), 49-60. https://doi.org/10.20448/journal.501.2017.42.49.60

Lee, U. H. M. S., Ismail, A., \& Sanusi, N. S. A. (2018). Ethical Climate as a Determinant of Organizational Commitment. International Journal of Asian Social Science, 8(8), 534-539. https://doi.org/10.18488/journal.1.2018.88.534.539

Lupu, C. (2017). The Relationship between Types of Intelligence and Study Profile Options. American Journal of Education and Learning, 2(1), 23-33. https://doi.org/10.20448/804.2.1.23.33

Luxmoore, J. (1999). Churches urged to help fight global corruption. Catholic New Times, 23(2), 12-13.

Lynch, T. (1999). Entrenching ethical and moral behaviour in the South African public sector. Administration Publican, 9(1), 84.

Madhusudhanan, S. (2018). Gender Responsive Budgeting: A Lesson Learned and Way Forward. International Journal of Applied Economics, Finance and Accounting, 2(1), 27-29. https://doi.org/10.33094/8.2017.2018.21.27.29

Manesh, M. H., Singh, J. S. K., \& Hussain, I. A. B. (2018). Transformational Leadership and Contextual Performance: A Quantitative Study among Nursing Staff in Kuala Lumpur. International Journal of Management and Sustainability, 7(2), 101-112. https://doi.org/10.18488/journal.11.2018.72.101.112 
Marquette, H. (2015). Corruption and collective action - Developmental Leadership Program. Birmingham: University of Birmingham.

Mutula, S. (2009). Public sector information management in east and southern Africa: Implications for FOI, democracy and integrity in government. International Journal of Information Management, 29(5), 333-341. https://doi.org/10.1016/j.ijinfomgt.2009.04.004

Neusner, J. (1988). The Theological Enemies of Religious Studies: Theology and Secularism in the Trivialization and Personalization of Religion in the West. Religion, 18, 21-35. https://doi.org/10.1016/S0048-721X(88)80016-2

Palys, T. (2008). Purposive sampling. In L. M. Given (Ed.), The Sage Encyclopedia of Qualitative Research Methods (Vol. 2, pp. 697-698). Sage: Los Angeles.

Rakodi, C. (2007). Understanding the roles of religion in development: The approach of the R\&D program. Religions and Development WP 7, Birmingham.

Suhonen, R., Stolt, M., Virtanen, H., \& Leino-Kilpi, H. (2011). Organisational ethics: a literature review. Nursing Ethics, 18(3), 285-303. https://doi.org/10.1177/0969733011401123

Tabachnick, B. G., \& Fidell, L. S. (2013). Using Multivariate Statistics (6th ed.). Boston: Pearson Education.

Treviño, L. K., Brown, M., \& Hartman, L. P. (2003). A qualitative investigation of perceived executive ethical leadership: Perceptions from inside and outside the executive suite. Human Relations, 56, 5-33. https://doi.org/10.1177/0018726703056001448

Wan Mohd Fathi, W. N. I., Ghani, E. K., Said, J., \& Puspitasari, E. (2017). Potential fraud scape in Islamic banks: The fraud triangle perspective. Global Journal of Al-Thaqafah, 7(2), 79-93. https://doi.org/10.7187/GJAT122017-3

Winkler, B. (2002). Which kind of transparency? On the Need for Effective Communication in Monetary Policy Making. Info Studies, 48, 401-27.

Yukl, G. (2013). Effective Leadership Behaviour: What We Know and What Questions Need More Attention. Academy of Management Perspectives, 26(4), 66-85. https://doi.org/10.5465/amp.2012.0088 